\title{
Atatürk Üniversitesi Açıöŏgretim Fakültesi’nde Genel Muhasebe Dersini Alan Öğrencilerin Performansını Etkileyen Faktörler
}

Meryem ÖZTÜRK*

\section{ÖZET}

Çalışmanın amacı, Atatürk Üniversitesi Açıköğretim Fakültesi'nde Genel Muhasebe dersini alan 13.772 ögrencinin yassları, cinsiyetleri, üniversiteye kayıt şekilleri, kayttl oldukları program ve ağırlı genel not ortalamaları ile Genel Muhasebe dersi notları arasında ilişki olup olmadığını ortaya koymak ve Genel Muhasebe dersinin performansina etki eden faktörleri tespit etmektir. T testi, Anova testi, korelasyon analizi ve çoklu regresyon analizinin yapıldiğı çalışmanın sonuçlarına göre, ögrencilerin \%32,5'inin dersi geçtiği, daha önce herhangi bir yüksekögretim kurumundan mezun olan ögrencilerin en başarılı ögrenciler olduğu, yaş grupları içinde en yüksek oranda AA ile dersi geçen ögrencilerin 50 yaşın üstünde olan ögrenciler olduğu, ağırlıkl genel not ortalaması 3,00'ün üzerinde olan ögrencilerin \%42'sinin AA, \%21,6'sının BA alarak dersi geçtiği, dersten AA alan ögrencilerin \%52,9'unun ağırlıkl genel not ortalamasının 3,00'ün üzerinde olduğu saptanmiştır. Ayrıca ögrencilerin Genel Muhasebe notları ile yaşları, kayıtlı oldukları program, kayıt şekilleri, ağırlıklı genel not ortalamaları arasında istatistiki olarak anlamlı bir ilişki olduğu ve bağımsız değişkenlerin Genel Muhasebe notunu \%46,4 açıkladığ belirlenmiştir.

Anahtar Kelimeler: Muhasebe Ĕ̆itimi, Genel Muhasebe, Öğrenci Performansı, Açıköğretim Fakültesi.

JEL Sinıflandırmast: M40, M41, I21, I23.

Factors Of Affecting Financial Accounting Performance Of Students In Atatürk University Open Education Faculty

\section{ABSTRACT}

The aim of the study is to determine whether there is a relationship between General Accounting grades of 13,772 students who took General Accounting course at Atatürk University Open Education Faculty and genders, ages, registration type, registered programs, overall grade point averages and the factors that affect the performance of the General Accounting course is to determine. In the study, $t$ test, anova test, correlation analysis and multiple regression analysis have used in the analysis of data. According to the results of the analysis, it has determined that $32.5 \%$ of the students have passed the course, the students who have previously graduated from any higher education institution are the most successful students, among the age groups, the students with the highest ratio $A A$ are the students who are over 50 years old, $42 \%$ of the students whose grade point averages have above 3.00 passed with $A A, 21.6 \%$ have passed the course with $B A, 52.9 \%$ of the students with grade $A A$ are above 3.00 of the overall grade point averages. In addition, it has determined that there is statistically significant relationship between the students' General Accounting grades and their ages, programs, registration type, the overall grade point averages and the predictor variables have explained 46.4\% of the General Accounting grade.

Keywords: Accountin Education, Financial Accounting, Student Performance, Open Education.

Jel Classification: M40, M41, I21, I23.

\footnotetext{
*Yrd. Doç. Dr. Meryem Öztürk, Atatürk Üniversitesi Açıköğretim Fakültesi, meryemozturk@atauni.edu.tr.
} 


\section{GİRiş}

Ekonomik ilişkilerin her geçen gün daha da karmaşık bir duruma geldiği günümüz dünyasında işletme faaliyetlerinin yatırım aşamasından başlayarak sürdürülmesi, rekabet edebilmek için gerekli stratejilerin geliştirilmesi ve/veya iflasa kadar bütün süreçlerde ihtiyaç duyulan sağlıklı, güvenilir, doğru, tam ve zamanında bilgi muhasebe departmanı tarafindan sunulmaktadır (Karasioğlu, 2011: 166). Muhasebe, işletmeleri kendisiyle ilgilenen kişi veya kurumlara tanıtan, tanıtma işini özel bir dil kullanarak gerçekleştiren bir sistemdir (Demir ve Çam, 2006: 1-2) ve bu sistem geçmişe yönelik sağlıkl, eksiksiz ve doğru bilgilerin sunulması ve aynı zamanda geleceğe yönelik planların hazırlanmasında doğru ve etkin karar alma sürecinde yol göstericidir. Başka bir ifade ile muhasebe, işletmelerin içinde bulunduğu mevcut duruma ilişkin bilgi sunarken aynı zamanda geleceğe ilişkin reel kararların alınması, risklerin ve firsatların tespit edilmesinde etkin rol oynamaktadır. Muhasebenin tüm bu fonksiyonları başarılı bir şekilde yerine getirebilmesi muhasebe mesleğini benimseyen kişilerin alacakları muhasebe eğitimine bağlıdır (Karasioğlu, 2011: 1665). Muhasebe eğitimi bir süreçtir ve bu sürecin amacı, işletme kararlarına katkı sağlayacak bilgilerin saptanması, toplanması, ölçülmesi, işlenmesi, kaydedilmesi, doğruluğunun denetlenmesi, raporlar halinde özetlenerek incelenmesi sonucu karar vermede kullanılabilecek bilgiye dönüştürebilmesi (Sayın vd, 2005: 101-102) için öğrencilerin kendi kendine öğrenme becerilerini geliştirmek/öğretmektir (Hatunoğlu, 2006: 193). Ayrıca öğrenmenin sürekliliğini sağlamak, muhasebe mesleğini seçen öğrencilerin meslek hayatlarında karşılaşabilecekleri işlemleri kolaylaştırmak (Tugay ve Ömürbek, 2014: 56) ve diğer disiplinlerde olduğu gibi yüksek kaliteli öğrenme çıktısını sağlamak muhasebe eğitiminin amaçları arasında yer almaktadır (Booth et al., 1999:277). Çıktıların beklentileri karşılama düzeyi, girdiler ve süreç içindeki teknolojik gelişmeler, öğreticiler ve fiziksel imkânlar gibi temel faktörlerin etkisi altındadır (Yücenurşen vd. 2016, 303).

Muhasebe eğitiminin her düzeyinde kişi farklı mesleki bilgi ve beceri kazanmakta ve muhasebe bilgi sürecine dâhil olmaktadır. Muhasebe bilgi sürecinde muhasebe meslek mensupları (Serbest Muhasebeci Mali Müşavir ve Yeminli Mali Müşavirler) ve ön muhasebe elemanı, ara eleman ve/veya yardımcı eleman olarak isimlendirilen çeşitli zamanlarda aynı işi yapan ancak farklı isimlerle anılan kişiler yer almaktadır. Farklı eğitim alanlarında, farklı düzeylerde eğitim almış bu kişiler karşılıklı etkileşim içinde muhasebe bilgi sürecine katkı sağlamaktadır (Altınay, 2016: 2144). Türkiye'de muhasebe eğitimi, orta öğretim kurumlarında lise düzeyinde ve yükseköğretim kurumlarında önlisans, lisans, yüksek lisans ve doktora düzeyinde verilmekte ve muhasebe alanında ihtiyaç duyulan nitelikli insan gücü yetiştirilmeye çalışılmaktadır (Tugay ve Ömürbek, 2014: 55). Önlisans ve lisans düzeyinde muhasebe eğitiminin verildiği birimlerden/fakültelerden biri de Açıöŏgretim Fakülteleridir. Açıköğretim genellikle uzaktan eğitim ile birbirine karıştırılan ve sıklıkla eşanlamlı olarak kullanılan bir kavram olup geleneksel olarak kapalı ve seçkin bir yüksek eğitim sisteminin bulunduğu ülkelerde yaygın olarak uygulanan ve önceden organize edilmiş, gönüllü ya da 
zorunlu öğrenme süreçlerini içeren bir eğitim sistemi olarak tanımlanmaktadır (Karataş, 2008:6). Türkiye'de yıllardır devam eden, gittikçe de büyüyen ve her geçen gün yenileri eklenen eğitim sorunlarının çözümüne katkı sağlamanın amaçlandığı eğitim-öğretimde Açıköğretim uygulamasının yer almasının nedenleri şu şekildedir (Hakan, 2017: 60):

- Her düzeyde eğitime olan talebin artması ve örgün eğitimin buna cevap verememesi başka bir ifadeyle yükseköğretimin önündeki yığılmaların ortadan kaldırılma isteği,

- Geleneksel eğitim uygulamaları ile aşılamayan eğitim sorunlarını yeni iletişim teknolojileri kullanarak çok ortamlı yaklaşımla çözme eğilimi,

- Kalkınmanın gerektirdiği insan gücü gereksiniminin karşılanma isteği,

- $\quad$ Her isteyene, hayat boyu eğitim sağlama görüşüdür.

Açıöğretim, derslere erişim ve eğitim ile diğer seçimlere nispeten özgürlük sağlandığı bir eğitim sistemidir. Eğitim mekânla sınırlı değildir, öğrencinin kendi ortamında gerçekleşmektedir (Karataş, 2008:6). Çalıştığı için örgün olarak önlisans ve lisans seviyesinde eğitim alamayan, bedensel engelli olduğu için yükseköğrenim yapamayan, ikamet ettiği ilde üniversite kazanamayıp farklı illerde okuma fırsatı olmayan, hükümlü olduğu için örgün eğitim alamayan vb. durumlarla (Balaban, 2017: 30) karşı karşıya olan öğrencilerin daha çok tercih ettiği bir eğitim sistemi olup herhangi bir yaş grubunda, herhangi bir gelir düzeyinde, herhangi bir meslek grubunda olan farklı mekânlardaki öğrencilerin iletişim teknolojileri yardımıyla eğitimlerini sürdürmesine olanak sağlamaktadır (Adıyaman, 2002: 92; Mutlu vd., 2006: 1271).

Dünyanın en zengin ve gelişmiş ülkelerinin de başvurduğu (Hakan, 2017: 67) bir eğitim-öğretim şekli olan açıöğretimin, 1981 yılında yürürlüğe giren 2547 sayılı Yükseköğretim Kanunu ile Anadolu Üniversitesi’nin bünyesinde yer alması sağlanmıştır. Böylece açıköğretim çalışmaları 1982 yılından itibaren bu fakülte tarafından sunulmaya başlanmıştır. 2010 yılında ise Atatürk Üniversitesi'nde Açıköğretim Fakültesi, İstanbul Üniversitesi'nde ise Açık ve Uzaktan Öğretim Fakültesi kurulmuş ve bu fakülteler de 2011 yılında eğitime başlamıştır (www.egitimtercihi.com, 2017). 1982 yılında 29.500 (www.anadolu.edu.tr, 2017) olan açıköğretime kayıtlı öğrenci sayısı her geçen yıl artmaya devam etmiştir. 2016-2017 Eğitim-Öğretim yılında herhangi bir yükseköğretim kurumunda kayıtlı olan önlisans ve lisans öğrencilerinin eğitim şekillerine göre dağılımı Tablo 1'de sunulmuştur. 
Tablo 1. 2016-2017 Türkiye'deki Yükseköğrenimdeki Kayıtlı Öğrenci Sayılarının Dağılımı

\begin{tabular}{|c|c|c|c|c|c|c|c|}
\hline & & \multicolumn{2}{|c|}{ Erkek } & \multicolumn{2}{|c|}{ Kadın } & \multicolumn{2}{|c|}{ Toplam } \\
\hline & Eğitim Şekli & Sayı & $\%$ & Sayı & $\%$ & Kişi & $\%$ \\
\hline \multirow{5}{*}{ Önlisans } & Örgün Öğretim & 450.293 & 12,7 & 316.892 & 10,3 & 767.185 & 11,6 \\
\hline & İkinci Öğretim & 228.880 & 6,5 & 113.561 & 3,7 & 342.441 & 5,2 \\
\hline & Uzaktan Eğitim & 20.149 & 0,5 & 13.760 & 0,4 & 33.909 & 0,5 \\
\hline & Aç1köğretim & 636.449 & 18,0 & 775.942 & 25,1 & 1.412 .391 & 21,3 \\
\hline & Toplam & 1.335 .771 & 37,7 & 1.220 .155 & 39,5 & 2.555 .926 & 38,6 \\
\hline \multirow{5}{*}{ Lisans } & Örgün Öğretim & 843.817 & 23,9 & 877.470 & 28,4 & 1.721 .287 & 25,9 \\
\hline & İkinci Öğretim & 245.742 & 6,9 & 182.137 & 5,9 & 427.879 & 6,5 \\
\hline & Uzaktan Eğitim & 11.816 & 0,4 & 16.191 & 0,5 & 28.007 & 0,4 \\
\hline & Açıköğretim & 1.100 .964 & 31,1 & 793.442 & 25,7 & 1.894 .406 & 28,6 \\
\hline & Toplam & 2.202 .339 & 62,7 & 1.869 .240 & 60,5 & 4.071 .579 & 61,4 \\
\hline \multicolumn{2}{|c|}{ Genel Toplam } & 3.538 .110 & 100,0 & 3.089 .395 & 100,0 & 6.627 .505 & 100,0 \\
\hline
\end{tabular}

Kaynak: https://istatistik.yok.gov.tr/yuksekogretimIstatistikleri/2017/2017_T1.pdf

Türkiye'de Yükseköğretim kurumlarına kayıtlı 6.627 .505 öğrencinin \%21,3’ü Açıköğretim Fakültelerinde Önlisans, \%28,6’sı lisans programlarına kayıtlıdır. Açıköğretim fakültelerindeki yükseköğretim öğrencileri, tüm yükseköğretim öğrencilerinin yarısını oluşturmaktadır. $\mathrm{Bu}$ bağlamda çalışmanın amacı, mevcut ve potansiyel öğrenci sayısı açısından Türkiye'de yükseköğretimde çok önemli yer tutan açıköğretim sisteminin uygulandığı üç fakülteden biri olan Atatürk Üniversitesi Açıköğretim Fakültesine (ATAAÖF) kayıtlı olup Genel Muhasebe dersini alan öğrencilerin başarı durumlarını öğrencilerin bazı özellikleri açısından incelemek ve öğrencilerin Genel Muhasebe dersindeki performanslarına etki eden faktörleri tespit etmektir.

\section{LITERATÜR ARAȘTIRMASI}

Muhasebe eğitimi üzerine yapılan yerli ve yabancı çalışmalarda üniversite düzeyinde ilk muhasebe dersinin ya da muhasebe derslerinin/muhasebe bölümü öğrencilerinin performansına etki eden faktörler, muhasebe dersini ilk defa alan öğrencilerin derse yönelik algıları/bakış açıları, farklı öğretim yöntemleri ve farklı araçlarla yapılan eğitimin öğrencinin başarısı/algısı üzerindeki etkisi, muhasebe öğreniminde başarıyı olumsuz etkileyen faktörler vb. üzerine odaklanılmıştır. Literatür araştırmasında bu çalışmalardan muhasebe bölümü öğrencileri/muhasebe dersi/derslerinin başarısını etkileyen faktörler üzerine yapılan çalışmalara yer verilmiştir.

Ramadan ve Quaraan (1994) yaptıkları çalışmada, Muhasebe İlkeleri I ve Muhasebe İlkeleri II derslerinin performansları üzerinde genel ortalama, cinsiyet, lisedeki alan, lise not ortalaması, Muhasebe I ve II dersini almadan önce tamamlanan kredi saati, üniversitedeki branş, öğrencinin dersi alma sayısının etkisini belirlemeyi amaçlamışlardır. Regresyon analizinin uygulandığı çalışmada, Muhasebe İlkeleri I dersinin en önemli belirleyicisinin dersi almadan önceki genel ortalama olduğu; Muhasebe İlkeleri I dersinin notunun ise Muhasebe İlkeleri II dersinin başarısını açıklayan en önemli değişken olduğu tespit edilmiştir. Ayrıca 
çalışmada geçmiş akademik performansın Muhasebe dersi başarısının önemli belirleyicisi olduğu; öğrencilerin cinsiyetlerinin ve bölümlerinin Muhasebe dersindeki başarıyı etkilediği; lise mezuniyet ortalamasının Muhasebe İlkeleri I performansının önemli bir belirleyicisi olduğu ve Muhasebe I notu ile Muhasebe II notu arasında pozitif yönlü ilişki olduğu sonucuna ulaşılmıştır.

Öğrencilerin özellikleri ile Muhasebe dersinden aldıkları notlar arasındaki ilişkiyi ölçmek amacıyla yaptıkları çalışmada Kalbers ve Weinstein (1999), korelasyon analizi ve regresyon analizini uygulamışlardır. Çalışmanın sonucunda öğrencilerin not ortalamalarının ve akademik başarı derecelerinin Muhasebe dersindeki başarının en güçlü ve belirleyici unsurları olduğu, performans açısından cinsiyetler arasında istatistiki olarak anlamlı farklılı̆̆ın olmadığı tespit edilmiştir.

Al-Rashed (2001) çalışmasında Kuveyt Üniversitesi Muhasebe bölümünden mezun olan öğrencilerin başarılarına etki eden faktörleri korelasyon analizi ve çoklu regresyon analizi ile belirlemeyi amaçlamıştır. Lise not ortalaması, lisede mezun olunan bölüm, belirli muhasebe derslerindeki başarı, birinci yılsonundaki genel ortalama, ikinci yılsonundaki genel ortalama ve bazı demografik değişkenlerin (yaş, cinsiyet, uyruk) kullanıldığı çalışmanın sonuçlarına göre; Muhasebe bölümünden mezun olan öğrencilerin genel ortalaması ile ilişkili en önemli değişkenin ikinci yılın sonundaki genel ortalama olduğu gözlenmiştir. Diğer değişkenlerin (uyruk, cinsiyet, yaş ve lise branşı) başarıyı tahmin etmede önemli bir gösterge olmadığı; Kuveytli öğrencilerin Kuveytli olmayan öğrencilerden üç Finansal Muhasebe dersi ve Maliyet Muhasebesi derslerinin hepsinde daha başarılı oldukları; lisede bilim branşından mezun olan öğrencilerin sanat branşından mezun olan öğrencilerden tüm Muhasebe dersleri ve genel ortalama açısından daha başarılı olduğu belirlenmiştir.

Öğrencilerin genel ortalamasının, cinsiyetlerinin, ırklarının, yaşlarının, ders yüklerinin, haftalık çalışma saatlerinin (herhangi bir işyerinde çalışıyorsa) muhasebe dersi başarısı üzerindeki etkilerini tespit etmek amaciyla Eikner ve Montondon (2001), t-testi, anova testi, basit regresyon ve çoklu regresyon analizini kullanmıştır. Çalışmanın sonucunda Genel ortalama, Muhasebe İlkeleri I dersi notunun ve yaşın muhasebe dersinin başarısı üzerinde etkisi olduğu tespit edilmiştir.

Waples ve Darayseh (2005) Amerika'daki Purdue Üniversitesi Muhasebe bölümü öğrencilerinin orta düzey Muhasebe I notlarını etkileyen faktörleri tespit etmeyi amaçlamışlardır. Çalışmada öğrencilerin orta düzey Muhasebe dersini almadan önceki ortalamaları, Finansal Muhasebeye Giriş dersi geçme notları, Yönetim Muhasebesine Giriş dersi geçme notları ve bilgi düzeyi skorları bağımsız değişken; orta düzey Muhasebe I notu bağımlı değişken olarak kullanılmıştır. Sonuçta temel finansal muhasebe bilgisi ve genel ortalamanın ilk orta düzey Muhasebe dersinin başarısında önemli göstergeler olduğu tespit edilmiştir. 
Kirk ve Spector (2006) Maliyet Muhasebesi dersinde öğrencilerin başarısını etkileyen faktörleri tespit etmek amacıyla yaptıkları çalışmalarında genel ortalama, Yönetim Muhasebesi ilkeleri ve İstatistik I dersindeki performansin Maliyet Muhasebesi dersinin başarısıyla ilişkili olduğunu tespit etmişlerdir. Öğrencilerin Matematik dersindeki başarıları, yaşları, cinsiyetleri ile Maliyet Muhasebesi dersindeki başarıları arasında ilişki olmadığı ve ayrıca orta düzey Muhasebe I dersini, Maliyet Muhasebesi dersinden önce alan öğrencilerin Maliyet Muhasebesi dersinde daha başarılı oldukları saptanmıştır.

Güngörmüş ve Uyar (2010) çalışmalarında muhasebe programına kayıtlı öğrenciler ile İşletme, Dış Ticaret, Bankacılık, Büro Yönetimi bölümlerine kayıtlı öğrencilerin Finansal Muhasebeye Giriş dersi performanslarını Kruskal-Wallis testi ile karşılaştırmışlardır. Çalışmada Muhasebe programına kayıtlı olan öğrencilerin Finansal Muhasebe dersinde diğer programlara kayıtlı öğrencilerden anlamlı derecede daha üstün performans gösterdikleri; Muhasebe programı öğrencilerinin üniversiteye yerleşme puanlarının ve genel ortalamalarının diğer programlara kayıtlı olan öğrencilerden daha düşük olduğu tespit edilmiştir.

Al-Twaijry (2010) yaptığı çalışmada, Yönetim Muhasebesi, Maliyet Muhasebesi, İleri Yönetim Muhasebesi derslerinde öğrencilerin başarılarını etkilemesi muhtemel faktörleri tespit etmeyi amaçlamıştır. Korelasyon analizi ve ortalamaların karşılaştırılması suretiyle verilerin analiz edildiği çalışmanın sonuçları; önceki muhasebe geçmişinin İleri Yönetim Muhasebesi dersinin başarısı üzerinde, matematik yeteneğinin ise Yönetim Muhasebesi dersi başarısı üzerinde anlamlı düzeyde etkisi olduğuna işaret etmektedir. Ayrıca sonuçlar, öğrencilerin Finansal Muhasebe dersindeki performans1 ile Yönetim Muhasebesi ve İleri Yönetim Muhasebesi dersi performansı ile anlamlı düzeyde ilişkili olduğunu; öğrencilerin Yönetim Muhasebesi dersi performansı ile Maliyet Muhasebesi ve İleri Yönetim Muhasebesi performansları arasında da anlamlı bir ilişki olduğunu göstermektedir.

Sekiz bağımsız değişken ile öğrencilerin muhasebe dersindeki performansını etkileyebilecek faktörleri tespit etmeyi amaçladıkları çalışmalarında Uyar ve Güngörmüş (2011), korelasyon analizi ve adımsal regresyon analizi yöntemini kullanmışlardır. Çalışmanın sonucunda cinsiyet ve üniversiteye giriş sınav puanı ile öğrenci performansı arasında ilişki olmadığı, yaş ile öğrenci performansı arasında negatif ilişki olduğu, lise ortalaması, önceki muhasebe bilgisi, not ortalaması, matematik notu ile Finansal Muhasebe dersindeki öğrenci performansıyla anlamlı düzeyde ilişkili olduğu tespit edilmiştir.

Garkaz vd. (2011) İslamic Azad Üniversitesindeki 450 muhasebe öğrencisinin akademik performansı üzerine etki eden faktörleri t-testini kullanarak tespit etmeye çalışmışlardır. Çalışmanın sonuçları, cinsiyet, diploma türü, derse ilgi ve istihdam durumu ile akademik performans arasında anlamlı düzeyde ilişki olduğunu, medeni durum ile ilişki olmadığını, muhasebeye ilgili olan öğrencilerin ilgisiz öğrencilere göre daha başarılı olduğunu göstermektedir. 
Nyikahadzoi vd. (2013) yaptıkları çalışmada, Zimbabwe Üniversitesinde yaş, cinsiyet, internete erişim, kayıt statüsünün bağımsız değişken; Muhasebe dersinin not ortalamasının ise bağımlı değişken olarak almışlardır. En küçük kareler yöntemi kullanılarak yapılan analiz sonucunda, bağımsız değişkenlerin bağımlı değişkenin \%25'ini açıkladığı; erkeklerin bayanlardan daha başarılı olduğu; internet erişimi ile akademik performans arasında pozitif yönlü ilişki olduğu tespit edilmiştir.

Kukreja ve AAli (2013) çalışmalarında, Bahreyn’deki Ahlia Üniversitesindeki lisans öğrencilerinin ilk iki Muhasebeye Giriş dersinin performansını analiz etmeyi amaçlamışlardır. Muhasebe II dersinin performansını en iyi açıklayan değişkenin Muhasebe I dersi notu olduğu, Muhasebe I dersinin performansını en iyi açıklayan değişkenin ise Muhasebe I dersini almadan önceki not ortalaması olduğunun tespit edildiği çalışmada, korelasyon analizi ve regresyon analizi yöntemleri kullanılmıştır.

Kuveyt’te bir yüksekokuldaki Muhasebe öğrencilerinin başarılarının belirleyicilerini tespit etmek üzere Almunais vd. (2014), ikinci sınıf öğrencilerine anket uygulamışlardır. Anket verilerine uygulanan regresyon analizi sonuçlarına göre, lise mezuniyetinin (beşeri bilimlere karşı fen bilimlerinden) öğrenci performansında en güçlü etkiye sahip olduğu; cinsiyet, bölüm, yaş, ödev verilme sıklı̆̆ı, etkileşim, sınav öncesi çalışma süresinin öğrencilerin Muhasebe dersi başarısı üzerinde anlamlı ve pozitif yönde ilişkili olduğu tespit edilmiştir.

Güney Afrika Üniversitesi'nde uzaktan eğitim ile Muhasebe bölümünde üç y1llık Finansal Muhasebe eğitimini tamamlayan 677 öğrencinin başarıları üzerinde yaşın, cinsiyetin, önceki muhasebe bilgisinin, matematik geçmişinin, akademik eğilimin etkisi olup olmadığını tespit etmek için Papageorgiou ve Halabi (2014) regresyon analizi yöntemini kullanmıştır. Analizin sonucunda Muhasebe I ve Muhasebe II dersi ile yaş arasında ilişki olmadığı ancak Muhasebe III dersi ile anlamlı ilişki olduğu tespit edilmiştir. Ayrıca cinsiyet ile Muhasebe dersleri arasında anlamlı ilişki olmadığı, önceki muhasebe bilgisi ile Muhasebe I dersi arasında anlamlı ilişki olduğu ancak II ve III arasında ilişki olmadığı, matematik geçmişi ile üç muhasebe dersi arasında da anlamlı ilişki olduğu belirlenmiştir.

Kuveyt’te bir yüksekokulda Maliyet Muhasebesi dersini alan 156 öğrencinin başarıları üzerinde etkili olan faktörleri tespit etmeye amaçladığı çalışmasında Alanzi (2015), verilerin analizinde korelasyon analizi ve regresyon analizi yöntemlerini uygulamıştır. Çalışmanın neticesinde Maliyet Muhasebesi dersi üzerinde, alan derslerinin not ortalamasının en önemli etkiye sahip olduğu; ikinci sırada ise derse devamın etkili olduğu; cinsiyet, yaş, uyruk, ortaöğretimdeki notların, ortaöğretimdeki alanın, ön koşullu notların ve genel ortalamanın öğrencinin başarısı üzerinde etkili olmadığı sonucuna ulaşılmıştır.

Yükseköğretim Muhasebe programına kayıtlı öğrencilerin performansları ile anlamlı ilişki olan faktörleri Jansen ve Villiers (2016) regresyon analizi ile saptamayı amaçlamışlardır. Çalışmanın sonucunda, öğrencilerin Muhasebe I başarı durumları ile 
Muhasebe III başarı durumları ve Muhasebe II başarı durumları ile Muhasebe III başarı durumları arasında pozitif ve anlamlı ilişki olduğu tespit edilmiştir. Ayrıca öğrencilerin lisedeki Matematik notlarının Muhasebe III dersinin başarısı ile önemli derecede ilişkili olduğu; yaşı daha küçük olan öğrencilerin daha büyük olan öğrencilerden ve erkek öğrencilerin bayan öğrencilerden daha başarılı oldukları saptanmıştır.

\section{3. ÇALIŞMANIN AMACI VE KAPSAMI}

Muhasebe bilimi kendine has farklı bir tekniğe ve farklı bir mantığa sahip bir bilim dalı olması nedeniyle öğrencilerin bireysel çalışmaları ile bu alanda başarılı olabilmeleri oldukça zordur. Bu noktada dersin veriliş şekli ve eğitim materyali öğrencinin başarısını etkileyebilecek faktörlerin başında yer alacaktır. Ayrıca dersin içeriği kadar eğitimi alan kişinin algı düzeyi, analitik yeteneği, cinsiyeti, daha önceki bilgi seviyesi, konuya olan ilgisi, kişisel özellikleri, genel not ortalaması, beklentileri, motivasyonu ve hatta bulunduğu kuşak bile dersin başarısında rol oynayabilir (Wooten, 1998: 357-358; Onat ve Akın, 2016: 149). Bu kapsamda çalışmanın amacı, öğrenme tekniklerinin öğreten açısından kısıtlı olduğu ATAAÖF'e kayıtlı Genel Muhasebe dersini alan öğrencilerin dersteki başarı durumlarını öğrencilerin özellikleri açısından analiz etmek ve dersin başarısında etkili olan faktörleri tespit etmektir.

Öğrenci başarılarının ölçülmesi ve değerlendirilmesi uzun soluklu eğitim-öğretim sürecinin en önemli unsurlarından biridir (Kutlu ve Öztürk, 2015: 9). Geleneksel yöntemlerde öğrenci başarısının değerlendirilmesi daha çok çoktan seçmeli ve kısa cevaplı testlerle, yazılı ve sözlü yoklamalarla yapılmaktadır (Gelbal ve Kelecioğlu, 2007: 136). ATA-AÖF'te hem vize hem de final/bütünleme sınavları test olarak yüz yüze yapılmakta olup sınavlarda dört yanlış cevap bir doğru cevabı götürmektedir. Öğrenciler vize sınavında ilk yedi üniteden, final/bütünleme sınavlarında ise tüm ünitelerden sorumlu tutulmaktadır. Vize, final ve bütünleme sınavlarında öğrencilere 5 seçenekli çoktan seçmeli 20'şer soru sorulmakta olup vize sınavının dersin ortalamasına katkısı \%30, final/bütünleme sınavının dersin ortalamasına katkısı ise \%70'tir. ATA-AÖF'te değerlendirme sistemi olarak bağıl değerlendirme sistemi uygulanmakta olup başarı notları harf notu, genel ortalamalar ise dörtlük sistem üzerinden hesaplanmaktadir.

Çalışmanın konusunu oluşturan Genel Muhasebe dersi ATA-AÖF’te Adalet Önlisans, Bankacılık ve Sigortacılık Önlisans, Büro Yönetimi ve Sekreterlik Önlisans, Dış Ticaret Önlisans, Emlak ve Emlak Yönetimi Önlisans, İşletme Lisans, İşletme Yönetimi Önlisans, Lojistik Önlisans, Sağlık Kurumları İşletmeciliği Önlisans, Sivil Havacılık ve Ulaştırma İşletmeciliği Önlisans, Turizm ve Otel İşletmeciliği Önlisans program müfredatlarında yer almaktadır. Genel Muhasebe dersi Lojistik Önlisans, Sivil Havacılık ve Ulaştırma İşletmeciliği Önlisans ile Turizm ve Otel İşletmeciliği Önlisans programlarının 2.sınıfında diğer programların 1.sınıfında okutulmaktadır. Bu kapsamda çalışmanın ana kütlesini 2016- 
2017 Eğitim-Öğretim yılı güz yarıyılında ATA-AÖF’e kayıtlı Genel Muhasebe dersini alan 13.772 öğrenci oluşturmaktadır. Çalışma, ana kütlenin tamamına uygulanmıştır.

\section{VERILERIN ANALIZI}

ATA-AÖF'ün bilgi işlem merkezinden alınan verilerin analizinde SPSS 20.0 istatistik programından yararlanılmış ve program vasıtasıyla frekans, yüzde, ortalama gibi tanımlayıcı istatistiki yöntemler ile t testi, Anova testi ve Pearson korelasyon analizi ve çoklu regresyon analizi yöntemleri uygulanmıştır.

\section{BULGULAR}

\subsection{Ana Kütlenin Özellikleri}

Genel Muhasebe dersini alan öğrencilerin \%44,6'sı kadın ve \%55,4'ü erkek; \%2,6'sının yaşı 20'den küçük, \%37,2'sinin yaşı 20-25 arasında, \%27,1'inin yaşı 31-40 arasında, \%8,2'sinin yaşı 41-50 arasında ve \%1,9'unun yaşı 50'den fazladır. Öğrencilerin \%43'ü Adalet Önlisans, \%4,3'ü Bankacılık ve Sigortacılık Önlisans, \%10,1'i Büro Yönetimi Önlisans, \%2,9’u Dış Ticaret Önlisans, \%7,6’sı Emlak ve Emlak Yönetimi Önlisans, \%9,3’ü İşletme Lisans, \%3,2'si İşletme Yönetimi Önlisans, \%1,4'ü Lojistik Önlisans, \%12,2'si Sağlık Kurumları İşletmeciliği Önlisans, \%4,3’ü Sivil Havacılık ve Ulaştırma İşletmeciliği Önlisans ve \%1,7'si ise Turizm ve Otel İşletmeciliği Önlisans programlarına kayıtlıdır.

Açıköğretim fakültelerine öğrenciler, farklı şekillerde kaydolabilmektedir. Bilindiği gibi Türkiye'de örgün ve ikinci öğretim kapsamında yükseköğretim programlarına genel olarak öğrenciler YGS/LYS/sınavsız geçiş ile yerleşmektedir. İlk yerleştirmede herhangi bir yükseköğretim kurumuna yerleşemeyen öğrenciler için ek yerleştirme yapılmaktadır. Aynı uygulamalar Açıköğretim fakülteleri için de geçerlidir. Genel Muhasebe dersini alan öğrencilerin \%33,4'ü YGS ile \%11,2 YGS-ek kontenjan ile öğrenim gördükleri programlara yerleşmişlerdir. Ayrıca Yükseköğretim kurumlarının herhangi bir lisans veya önlisans programından mezun olan veya okuyan öğrenciler, sınavsız olarak Açıköğretim Fakültelerinin uygun programlarında okuma firsatı bulabilmektedir. Bu bağlamda Genel Muhasebe dersini alan öğrencilerin \%26,2'si herhangi bir yükseköğretim kurumuna kayıtlı ve \%23,3'ü herhangi bir yükseköğretim kurumundan mezun olup ATA-AÖF’e ikinci üniversite kapsamında kayıtlıdır. Genel Muhasebe dersini alan öğrencilerin \%5,1'i ise YÖS (Yabancı Uyruklu Öğrenci Sınav1- Türkiye'deki yükseköğretim kurumlarında okumak isteyen öğrencilerin girecekleri ve sonuçlarını bu kurumlara kabul için başvururken kullanabilecekleri bir sınavdır.) kapsamında kayıtlı oldukları programa yerleşmiştir. Mesleki ve teknik ortaöğretim kurumlarından mezun olan öğrenciler, gerekli şartları taşıdıkları ve istedikleri takdirde bitirdikleri programın devamı niteliğinde veya buna yakın programların uygulandığı 
önlisans programlarına yerleşebilmektedir (www.osym.gov.tr, 2017) ${ }^{1}$. Bu kapsamda veya başka bir yükseköğretim programında kayıtlı olup yatay geçiş ile şuan kayıtlı olduğu programa geçen öğrenciler, Genel Muhasebe dersini alan öğrencilerin \%5,2'ini oluşturmaktadır.

\subsection{Genel Muhasebe Harf Notlarının Cinsiyete, Yaşa, Kayıtlı Olunan Programa, Kayıt Şekline ve AGNO’ya Göre Dağılımı ile Aralarındaki İlişkiye Ait Bulgular}

Bu bölümde Genel Muhasebe dersini alan öğrencilerin dersteki başarılarının cinsiyete, yaşa, kayıtlı olunan programa, kayıt şekline, ağırlıklı genel not ortalamasına (AGNO) göre farklılaşıp farklılaşmadığını tespit edebilmek için yapılan t testi ve Anova testi sonuçlarına ve ayrıca Genel Muhasebe harf notlarının dağılımına yer verilmiştir.

Genel Muhasebe dersini alan öğrencilerin \%67,5’i (9.299 öğrenci) FF alarak dersten kalmış, \%32,5'i (4.473 öğrenci) ise dersi geçmiştir. Genel Muhasebe dersini alan öğrencilerin $\% 2,1$ 'i CC ile \%9,2'si CB ile \%9,4'ü BB ile \%5,9’u BA ve AA ile dersi geçmiştir. Dersi geçen öğrencilerin (4.473 öğrencinin) ise \%6,3'ü CC ile \%28,3'ü CB ile \%29'u BB ile \%18,3'ü BA ile ve \%18,1'i AA ile geçmiştir. Dersi alan öğrencilerin dersten aldıkları harf notlarının cinsiyete göre dağılımları ve t testi sonuçları tabloda sunulduğu gibidir.

Tablo 2. Genel Muhasebe Harf Notlarının Öğrencilerin Cinsiyetine Göre Dağılımı ve $\mathrm{T}$ Testi Sonuçları

\begin{tabular}{|c|c|c|c|c|c|c|c|c|c|c|c|}
\hline & \multicolumn{6}{|c|}{ GENEL MUHASEBE HARF NOTLARI } & \multirow{2}{*}{ Ort. } & \multirow{2}{*}{ t } & \multirow{2}{*}{$\mathbf{P}$} \\
\hline & & & FF & CC & CB & BB & BA & AA & & & \\
\hline \multirow{4}{*}{$\frac{\sqrt[n]{n}}{\sqrt[n]{n}}$} & & Frekans & 4.185 & 132 & 521 & 573 & 363 & 366 & & \multirow{4}{*}{,- 970} & \multirow{4}{*}{,332 } \\
\hline & Kadın & Cinsiyet iç. \% & 68,2 & 2,1 & 8,5 & 9,3 & 5,9 & 6,0 & 1,66 & & \\
\hline & \multirow{2}{*}{ Erkek } & Frekans & 5.114 & 151 & 746 & 722 & 456 & 443 & \multirow{2}{*}{1,68} & & \\
\hline & & Cinsiyet iç. \% & 67,0 & 2,0 & 9,8 & 9,5 & 6,0 & 5,8 & & & \\
\hline
\end{tabular}

Öğrencilerin cinsiyetleri ile Genel Muhasebe dersi başarı durumları arasında istatistiki olarak anlamlı bir ilişki bulunmamaktadır ( $\mathrm{P}>0,05)$. Bayan öğrencilerin \%68,2'si Genel Muhasebe dersinden kalmış, \%6'sı ise dersi AA ile geçmiştir. Erkek öğrencilerin \%67'si Genel Muhasebe dersinden kalmış, \%5,8'i dersten AA ile geçmiştir. Bayanların Genel Muhasebe dersi ortalaması 1,66 iken erkeklerin ortalaması 1,68'dir.

Genel Muhasebe dersi notlarının öğrencilerin yaşlarına göre dağılımları ve Anova testi sonuçları Tablo 3 'te gösterilmiştir.

\footnotetext{
${ }^{1}$ Meslek Liselerinden Yükseköğretim Kurumlarına sınavsız geçiş 2017 yılı itibarıyla kaldırılmıştır.
} 
Tablo 3. Genel Muhasebe Harf Notlarının Öğrencilerin Yaşlarına Göre Dağılımı ve Anova Testi Sonuçları

\begin{tabular}{|c|c|c|c|c|c|c|c|c|c|c|c|}
\hline & \multicolumn{6}{|c|}{ GENEL MUHASEBE HARF NOTLARI } & \multirow[b]{2}{*}{ Ort. } & \multirow[b]{2}{*}{$\mathbf{F}$} & \multirow[b]{2}{*}{$\mathbf{P}$} \\
\hline & & & FF & CC & CB & $\mathrm{BB}$ & BA & AA & & & \\
\hline \multirow{12}{*}{$\sum_{i}^{\infty}$} & 20’den & Frekans & 258 & 11 & 29 & 35 & 12 & 9 & \multirow[b]{2}{*}{1,51} & \multirow{12}{*}{83,667} & \multirow{12}{*}{,000 } \\
\hline & küçük & Yaș iç. \% & 72,9 & 3,1 & 8,2 & 9,9 & 3,4 & 2,5 & & & \\
\hline & $20-25$ & Frekans & 3.822 & 86 & 380 & 398 & 243 & 191 & \multirow{2}{*}{1,51} & & \\
\hline & aras1 & Yaş iç. \% & 74,6 & 1,7 & 7,4 & 7,8 & 4,7 & 3,7 & & & \\
\hline & \multirow{2}{*}{$\begin{array}{l}26-30 \\
\text { aras1 }\end{array}$} & Frekans & 2.257 & 65 & 284 & 256 & 154 & 167 & \multirow{2}{*}{1,59} & & \\
\hline & & Yaş iç. \% & 70,9 & 2,0 & 8,9 & 8,0 & 4,8 & 5,2 & & & \\
\hline & \multirow{2}{*}{$\begin{array}{l}31-40 \\
\text { aras1 }\end{array}$} & Frekans & 2.209 & 99 & 426 & 428 & 286 & 279 & \multirow{2}{*}{1,84} & & \\
\hline & & Yaş iç. \% & 59,3 & 2,7 & 11,4 & 11,5 & 7,7 & 7,5 & & & \\
\hline & \multirow{2}{*}{$\begin{array}{l}41-50 \\
\text { aras1 }\end{array}$} & Frekans & 627 & 18 & 116 & 142 & 94 & 132 & \multirow{2}{*}{1,98} & & \\
\hline & & Yaş iç. \% & 55,5 & 1,6 & 10,3 & 12,6 & 8,3 & 11,7 & & & \\
\hline & \multirow{2}{*}{$\begin{array}{l}50 \text { 'den } \\
\text { fazla }\end{array}$} & Frekans & 126 & 4 & 32 & 36 & 30 & 31 & \multirow{2}{*}{2,12} & & \\
\hline & & Yaş iç. \% & 48,6 & 1,5 & 12,4 & 13,9 & 11,6 & 12,0 & & & \\
\hline
\end{tabular}

Genel Muhasebe dersi başarı durumları öğrencilerin yaşlarına göre istatistiki olarak anlamlı düzeyde değişmektedir $(\mathrm{P}<0,05)$. Yaşı 20'nin altında olan öğrencilerin dersten aldıkları notların ortalaması 1,51 iken yaşı 41-50 arasında olan öğrencilerin ortalaması 1,98 ve 50'nin üstünde olan öğrencilerin ortalaması ise 2,13'tür. Yaş1 50'nin üstünde olan öğrencilerin \%51,4'ü dersten geçmiş olup yaş grupları içinde dersten en yüksek geçme oranına sahip öğrencileri oluşturmaktadır. Yine yaş grupları içinde en yüksek oranda AA alarak dersi geçen öğrenciler 50 yaşın üstünde olan öğrencilerdir. Özetle yaşı 25 'in altında olan öğrenciler Genel Muhasebe dersinde en başarısız; 50’nin üzerinde olan öğrenciler ise en başarılı öğrencilerdir. Bunun nedeni yaşı $25^{\prime}$ in altında olan öğrencilerin henüz bilinçsiz olmaları, yaşı 50'nin üzerinde olanların ise hayat kaygılarının azalması, emeklilikte diplomanın sağlayacağı avantajlardan yararlanma istekleri ve bu nedenle de derslerini daha ciddiye almaları olabilir.

Tablo 4. Genel Muhasebe Harf Notlarının Öğrencilerin Kayıtlı Oldukları Programa Göre Dağılımı ve Anova Testi Sonuçları

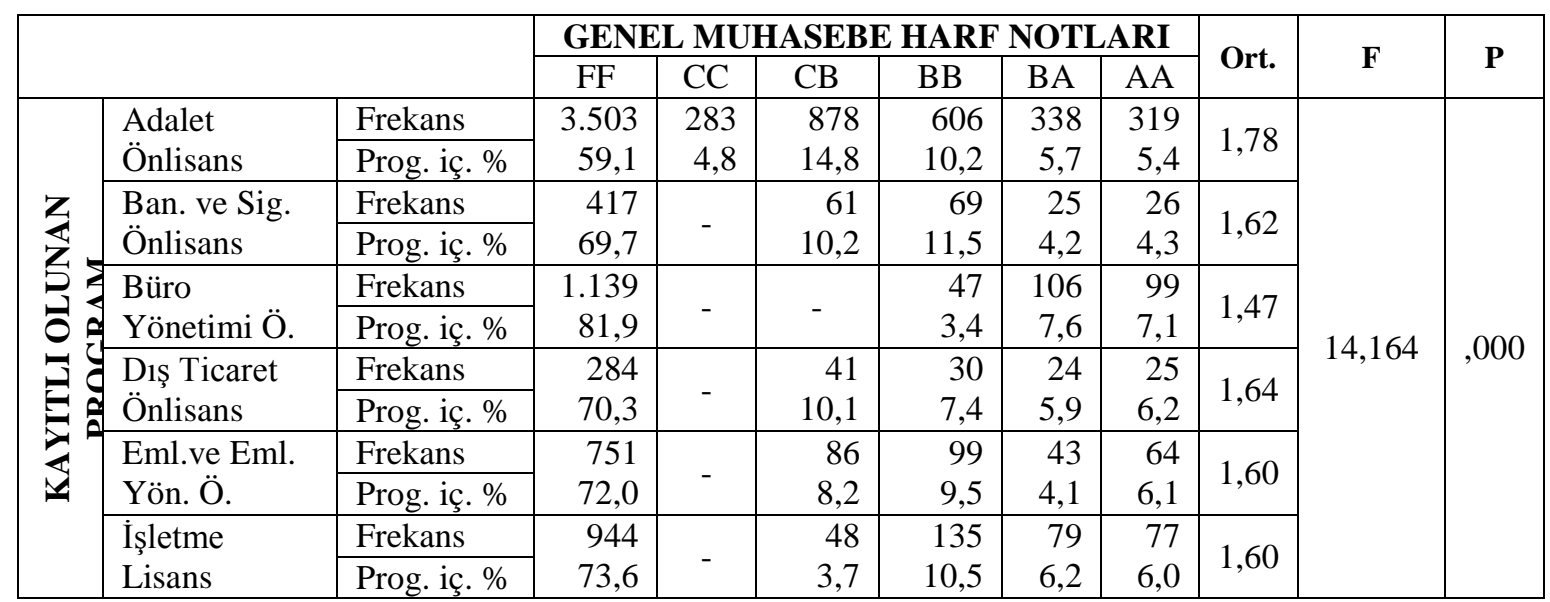




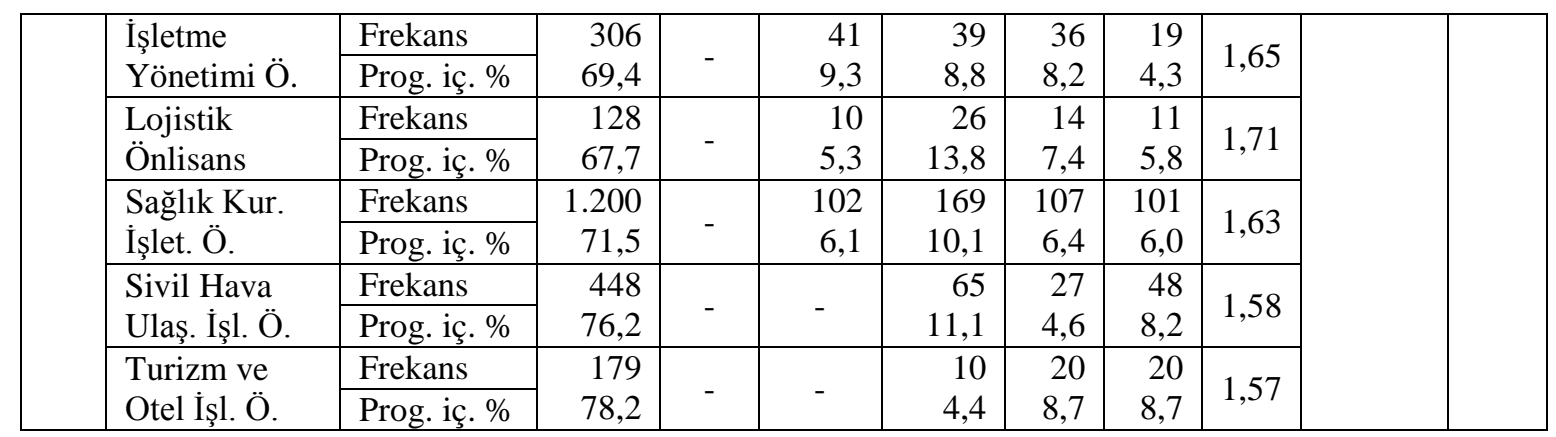

Öğrencilerin kayıtlı oldukları program ile Genel Muhasebe notları arasında istatistik olarak anlamlı bir fark bulunup bulunmadığına dair yapılan Anova testi sonuçlarına göre iki değişken arasında anlamlı $(\mathrm{P}<0,05)$ bir farklılık olduğu tespit edilmiştir. Kayıtlı olunan program açısından Adalet programı öğrencileri hem dersten geçen öğrenci oranı ile hem de dersin harf notlarının ortalaması bakımından en başarılı öğrencilerdir. Adalet Önlisans programı öğrencilerinin \%40,9'u (dersten kalan öğrenci \%59,1) dersi geçmiştir. Bu programa kayıtlı olan öğrencilerin \%37,8'i herhangi bir yükseköğretim kurumunda öğrenci ve \%39,2'si herhangi bir yükseköğretim kurumundan mezun olup ATA-AÖF'te ikinci üniversite okumaktadır. Adalet Önlisans programından mezun olan öğrenciler DGS'de (Dikey Geçiş Sınavı) başarılı olmaları halinde Hukuk Fakültelerine kaydolabilmektedir. Bu durum LYS ile Hukuk Fakültesi kazanamayan öğrencilere Hukuk Fakültelerine yerleşebilmeleri için alternatif bir çözüm şansı vermektedir. Adalet Önlisans programına kayıtlı öğrencilerin diğer öğrencilere oranla daha başarılı olmasının nedenlerinden biri bu durumun farkında olmaları ve bu amaçla bu programda öğrenim görmeleri olabilir. Genel Muhasebe dersinde en başarısız öğrenciler 1,47 ortalama ile Büro Yönetimi Önlisans programına kayıtlı öğrenciler olup öğrencilerin \%81,9'u dersten kalmıştır. Kayıtlı olunan programa göre en yüksek oranda AA alarak dersi geçen öğrenciler ise Sivil Hava Ulaştırma İşletmeciliği Önlisans programına kayıtlı öğrencilerdir.

Tablo 5. Genel Muhasebe Harf Notlarının Öğrencilerin Kayıt Türlerine Göre Dağılımı ve Anova Testi Sonuçları

\begin{tabular}{|c|c|c|c|c|c|c|c|c|c|c|c|}
\hline & \multicolumn{6}{|c|}{ GENEL MUHASEBE HARF NOTLARI } & \multirow{2}{*}{ Ort. } & \multirow[b]{2}{*}{$\mathbf{F}$} & \multirow{2}{*}{$\mathbf{P}$} \\
\hline & & & FF & CC & CB & BB & BA & AA & & & \\
\hline \multirow{12}{*}{ 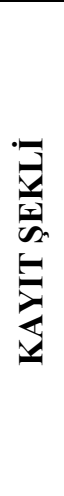 } & II.Üniversite & Frekans & 2.439 & 117 & 405 & 317 & 186 & 150 & \multirow{2}{*}{1,63} & \multirow{12}{*}{155,120} & \multirow{12}{*}{,000 } \\
\hline & (Öğrenci) & Kay.ş.iç.\% & 67,5 & 3,2 & 11,2 & 8,8 & 5,1 & 4,2 & & & \\
\hline & \multirow{2}{*}{$\begin{array}{l}\text { II.Üniversite } \\
\text { (Mezun) }\end{array}$} & Frekans & 1.584 & 98 & 426 & 440 & 263 & 398 & \multirow{2}{*}{2,08} & & \\
\hline & & Kay.ş.iç.\% & 49,4 & 3,1 & 13,3 & 13,7 & 8,2 & 12,4 & & & \\
\hline & \multirow{2}{*}{ YGS } & Frekans & 3.523 & 51 & 270 & 338 & 242 & 170 & \multirow{2}{*}{1,49} & & \\
\hline & & Kay.ş.iç.\% & 76,7 & 1,1 & 5,9 & 7,4 & 5,3 & 3,7 & & & \\
\hline & \multirow{2}{*}{ YGS (Ek) } & Frekans & 1.206 & 15 & 95 & 108 & 72 & 51 & \multirow{2}{*}{1,46} & & \\
\hline & & Kay.ş.iç.\% & 78,0 & 1,0 & 6,1 & 7,0 & 4,7 & 3,3 & & & \\
\hline & \multirow{2}{*}{ YÖS } & Frekans & 77 & & 6 & 12 & 1 & 4 & \multirow{2}{*}{1,47} & & \\
\hline & & Kay.ş.iç.\% & 77,0 & - & 6,0 & 12,0 & 1,0 & 4,0 & & & \\
\hline & \multirow{2}{*}{$\begin{array}{l}\text { Sınavsız/ } \\
\text { Yatay Geçiş }\end{array}$} & Frekans & 470 & 2 & 65 & 80 & 55 & 36 & \multirow{2}{*}{1,71} & & \\
\hline & & Kay.ş.iç.\% & 66,4 & 0,3 & 9,2 & 11,3 & 7,8 & 5,1 & & & \\
\hline
\end{tabular}


Öğrencilerin kayıt şekilleri ile Genel Muhasebe harf notları arasında \%5 önem düzeyinde anlamlı bir farklılaşmanın olduğu tespit edilmiştir. Herhangi bir yükseköğretim kurumuna kayıtlı olup ATA-AÖF'te ikinci üniversite kapsamında kayıtlı olan öğrencilerin ortalaması 1,63; daha önce herhangi bir yükseköğretim kurumundan mezun olup ATA-AÖF’e ikinci üniversite kapsamında kayıtlı olan öğrencilerin Genel Muhasebe dersi harf notu ortalamaları 2,08; YGS ile ATA-AÖF'e kayıtlı olan öğrencilerin Genel Muhasebe dersi harf notu ortalamaları 1,49; YGS ile ek yerleştirme sonucu ATA-AÖF'e kayıtlı olan öğrencilerin harf not ortalamaları 1,46; YÖS ile ATA-AÖF'e kayıtlı olan öğrencilerin harf notu ortalamaları 1,48; sınavsız geçiş ya da yatay geçiş ile ATA-AÖF'e kayıtlı olan öğrencilerin harf notu ortalamaları 1,71'dir. Öğrencilerin kayıtlı oldukları programa yerleşme durumlarına göre Genel Muhasebe dersinde hem geçme hem de yüksek not alma noktasında en başarılı öğrenciler, daha önce bir yükseköğretim kurumundan mezun olup ATA-AÖF'e ikinci üniversite kapsamında kayıtlı olan öğrencilerdir. Bu kapsamda kayıtlı olan öğrencilerin \%50,6'sı dersi geçmiştir. Ayrıca bu kapsamda kayıtlı olan öğrencilerin \%12,4'ü dersten AA ile \%8,2'si ise BA ile geçmiştir. Derste en başarısız olan öğrenciler ise YGS, YGS ek kontenjan ve YÖS ile kayıtlı olan öğrenciler olup bu öğrencilerin sadece \%22-23’ü dersi geçmiştir.

Tablo 6. Genel Muhasebe Harf Notlarının Öğrencilerin AGNO’larına Göre Dağılımı ve Anova Testi Sonuçları

\begin{tabular}{|c|c|c|c|c|c|c|c|c|c|c|c|}
\hline & \multicolumn{6}{|c|}{ GENEL MUHASEBE HARF NOTLARI } & \multirow{2}{*}{ Ort. } & \multirow{2}{*}{$\mathbf{F}$} & \multirow{2}{*}{$\mathbf{P}$} \\
\hline & & & $\mathrm{FF}$ & CC & CB & BB & BA & AA & & & \\
\hline \multirow{18}{*}{$\underbrace{0}_{\substack{Z \\
\hdashline}}$} & \multirow{3}{*}{$\begin{array}{l}\text { 1,00’den } \\
\text { az }\end{array}$} & Frekans & 6.455 & 38 & 252 & 187 & 92 & 31 & \multirow{3}{*}{1,16} & \multirow{18}{*}{2377,960} & \multirow{18}{*}{, 000} \\
\hline & & AGNO iç.\% & 91,5 & 0,5 & 3,6 & 2,7 & 1,3 & 0,4 & & & \\
\hline & & Gen. Muh. iç.\% & 69,4 & 13,4 & 19,9 & 14,4 & 11,2 & 3,8 & & & \\
\hline & \multirow{3}{*}{$\begin{array}{l}1,00-1,49 \\
\text { aras1 }\end{array}$} & Frekans & 1.379 & 54 & 177 & 161 & 102 & 39 & \multirow{3}{*}{1,53} & & \\
\hline & & AGNO iç.\% & 72,1 & 2,8 & 9,3 & 8,4 & 5,3 & 2,0 & & & \\
\hline & & Gen. Muh. iç.\% & 14,8 & 19,1 & 14,0 & 12,4 & 12,5 & 4,8 & & & \\
\hline & \multirow{3}{*}{$\begin{array}{l}1,50-1,99 \\
\text { aras1 }\end{array}$} & Frekans & 873 & 61 & 253 & 207 & 98 & 62 & \multirow{3}{*}{1,83} & & \\
\hline & & AGNO iç.\% & 56,2 & 3,9 & 16,3 & 13,3 & 6,3 & 4,0 & & & \\
\hline & & Gen. Muh. iç.\% & 9,4 & 21,6 & 20,0 & 16,0 & 12,0 & 7,7 & & & \\
\hline & \multirow{3}{*}{$\begin{array}{l}2,00-2,49 \\
\text { aras1 }\end{array}$} & Frekans & 401 & 66 & 245 & 229 & 122 & 94 & \multirow{3}{*}{2,28} & & \\
\hline & & AGNO iç.\% & 34,7 & 5,7 & 21,2 & 19,8 & 10,5 & 8,1 & & & \\
\hline & & Gen. Muh. iç.\% & 4,3 & 23,3 & 19,3 & 17,7 & 14,9 & 11,6 & & & \\
\hline & \multirow{3}{*}{$\begin{array}{l}2,50-2,99 \\
\text { aras1 }\end{array}$} & Frekans & 154 & 56 & 237 & 288 & 185 & 155 & \multirow{3}{*}{2,78} & & \\
\hline & & AGNO iç.\% & 14,3 & 5,2 & 22,0 & 26,8 & 17,2 & 14,4 & & & \\
\hline & & Gen. Muh. iç.\% & 1,7 & 19,8 & 18,7 & 22,2 & 22,6 & 19,2 & & & \\
\hline & \multirow{3}{*}{$\begin{array}{l}\text { 3,00'den } \\
\text { fazla }\end{array}$} & Frekans & 37 & 8 & 103 & 223 & 220 & 428 & \multirow{3}{*}{3,40} & & \\
\hline & & AGNO iç.\% & 3,6 & 0,8 & 10,1 & 21,9 & 21,6 & 42,0 & & & \\
\hline & & Gen. Muh. iç.\% & 0,4 & 2,8 & 8,1 & 17,2 & 26,9 & 52,9 & & & \\
\hline
\end{tabular}

Öğrencilerin AGNO’ları ile Genel Muhasebe harf notları arasında da \%5 önem düzeyinde anlamlı bir ilişkinin olduğu tespit edilmiştir. AGNO'su 1,00'ın altında olan öğrencilerin Genel Muhasebe dersi harf notlarının ortalaması 1,16; AGNO'su 1,00-1,49 arasında olan öğrencilerin Genel Muhasebe dersi harf notlarının ortalaması 1,53; AGNO'su 1,50-1,99 arasında olan öğrencilerin Genel Muhasebe dersi harf notlarının ortalaması 1,83; 
AGNO'su 2,00-2,49 arasında olan öğrencilerin Genel Muhasebe dersi harf notlarının ortalaması 2,28; AGNO'su 2,50-2,99 arasında olan öğrencilerin Genel Muhasebe dersi harf notlarının ortalaması 2,78 ve 3,00'ın üzerinde olan öğrencilerin Genel Muhasebe dersi harf notlarının ortalaması ise 3,40’tır. AGNO'su 1,00'in altında olan öğrencilerin \%91,5'i; 1,001,49 arasında olan öğrencilerin \%72,1'i; 1,50-1,99 arasında olan öğrencilerin \%56,2'si Genel Muhasebe dersinden FF alarak kalmıştır. AGNO'su 3,00'ün üzerinde olan öğrencilerin \%42'si AA, \%21,6'sı BA, \%21,9'u Genel Muhasebe dersinden BB alarak geçmiştir. Genel olarak değerlendirildiğinde AGNO'su yüksek olan öğrencilerin Genel Muhasebe dersi notları da yüksek, AGNO'su düşük olan öğrencilerin ise Genel Muhasebe dersi notları da düşüktür.

\subsection{Korelasyon Analizi Sonuçları}

Korelasyon analizi, değişkenlerin bağımlı veya bağımsız olması dikkate alınmaksızın değişkenler arasındaki ilişkinin yönünü ve derecesini belirlemek amacıyla kullanılan istatistiki yöntemdir (Durmuş vd., 2011:143). Korelasyon katsayısı -1 ile 1 arasında değerler alır, katsayının 1 olması mükemmel pozitif bir ilişkiyi; -1 olması mükemmel negatif bir ilişkiyi; 0 olması ilişkinin olmadığını gösterir. Katsayının değeri 0,00 ile 0,30 arasında ise değişkenler arasında düşük düzeyde, 0,31 ile 0,69 arasında ise orta düzeyde, 0,70 ile 1 arasında ise yüksek düzeyde ilişkinin olduğu anlamına gelir (Büyüköztürk, 2011: 31). Değişkenler arasında ilişkinin yönünü ve derecesini belirlemek amacıyla yapılan korelasyon analizi sonuçları tabloda gösterildiği gibidir.

Tablo 7. Öğrencilerin Genel Muhasebe Harf Notları ile Bağımsız Değişkenler Arasındaki İlişkiye Ait Korelasyon Analizi

\begin{tabular}{|l|l|c|c|c|c|c|c|}
\hline Değişkenler & & $\mathrm{A}$ & $\mathrm{B}$ & $\mathrm{C}$ & $\mathrm{D}$ & $\mathrm{E}$ & $\mathrm{F}$ \\
\hline \multirow{2}{*}{ AGNO (A) } & Kor. kat. & 1 & & & & & \\
\hline & $\mathrm{P}$ & & & & & & \\
\hline \multirow{2}{*}{ Cinsiyet (B) } & Kor. kat. &, $032^{* *}$ & 1 & & & & \\
\hline & $\mathrm{P}$ &, 000 & & & & & \\
\hline \multirow{2}{*}{ Yaş (C) } & Kor. kat. &, $195^{* *}$ &, $101^{* *}$ & 1 & & & \\
\cline { 2 - 8 } & $\mathrm{P}$ &, 000 &, 000 & & & & \\
\hline \multirow{2}{*}{$\begin{array}{l}\text { Dersin alınış sayıs1 } \\
\text { (D) }\end{array}$} & Kor. kat. &,$- 043^{* *}$ &,- 014 &,$- 034^{* *}$ & 1 & & \\
\hline & $\mathrm{P}$ &, 000 &, 104 &, 000 & & & \\
\hline \multirow{2}{*}{ Kayıt Türü (E) } & Kor. kat. &,$- 298^{* *}$ &,$- 050^{* *}$ &,$- 272^{* *}$ &, $118^{* *}$ & 1 & \\
\cline { 2 - 8 } & $\mathrm{P}$ &, 000 &, 000 &, 000 &, 000 & & \\
\hline $\begin{array}{l}\text { Genel Muhasebe } \\
\text { Notu (F) }\end{array}$ & Kor. kat. &, $677^{* *}$ &, 008 &, $166^{* *}$ &,$- 077^{* *}$ &,$- 220^{* *}$ & 1 \\
\cline { 2 - 8 } & $\mathrm{P}$ &, 000 &, 332 &, 000 &, 000 &, 000 & \\
\hline
\end{tabular}

Genel Muhasebe dersini alan öğrencilerin dersten aldıkları notlar ile AGNO'ları arasında pozitif yönlü orta düzeyde bir ilişki tespit edilmiştir. Öğrencilerin AGNO’ları arttıkça Genel Muhasebe notları da \%67,7 düzeyinde artmaktadır. Genel Muhasebe dersi notları ile yaş arasında da pozitif yönlü düşük düzeyde anlamlı bir ilişki olduğu belirlenmiştir. Buna göre öğrencilerin yaşları arttıkça Genel Muhasebe dersindeki başarıları da artmaktadır. 
Dersin alınış sayısı ile Genel Muhasebe notları arasında çok düşük düzeyde de olsa negatif yönlü istatistiki olarak anlamlı ilişki olduğu saptanmıştır kısaca dersin alınış sayısı arttıkça öğrencilerin Muhasebe dersindeki başarısı azalmaktadır. Genel Muhasebe notu ile kayıt türü (ikinci üniversite-mezun (0), diğerleri (1)) arasında negatif yönlü korelasyon söz konusudur ve bu durum daha önce herhangi bir yükseköğretim kurumundan mezun olup ikinci üniversite kapsamında öğrenim gören öğrencilerin diğer öğrencilere göre daha başarılı olduklarını göstermektedir.

\subsection{Genel Muhasebe Dersinin Notunu Yordayan Değişkenler}

Öğrencilerin Genel Muhasebe dersindeki başarılarını etkileyen faktörleri ve bu faktörlerin etkilerini belirleyebilmek için çoklu regresyon analizi uygulanmıştır. Regresyon analizi, aralarında sebep-sonuç ilişkisi olan iki ya da daha fazla değişken arasındaki ilişkiyi ölçmek için kullanılan analiz yöntemidir (Büyüköztürk, 2011: 91). Regresyon analizinde Genel Muhasebe notu bağımlı değişken olarak alınmıştır ve FF-1, CC-2, CB-2,5, BB-3, BA3,5, AA-4 olarak kodlanmıştır. Cinsiyet, yaş, kayıt türü, AGNO, dersin kaçıncı kez alındığı, kayıtlı olunan program (dersin yer aldığı sınıf) değişkenleri bağımsız değişken olarak alınmıştır. Cinsiyet değişkeninde bayanlar 0, erkekler 1 olarak; kayıt türü değişkeninde daha önce herhangi bir yükseköğretim kurumundan mezun olup ikinci üniversite kapsamından kayıtlı olanlar 0 , diğerleri 1 olarak; dersi 2.sınıfta alanlar 0, 1.sınıfta alanlar 1 olarak kodlanmıştır.

Tablo 8. Çoklu Regresyon Analizi Sonuçları

\begin{tabular}{|c|c|c|c|c|c|c|}
\hline $\begin{array}{l}\text { Yordanan } \\
\text { Değișken }\end{array}$ & $\begin{array}{l}\text { Yordayıcı } \\
\text { Değișken }\end{array}$ & B & $\begin{array}{c}\text { Standart } \\
\text { Hata }\end{array}$ & $\beta$ & $\mathrm{t}$ & $\mathrm{P}$ \\
\hline \multirow{6}{*}{$\begin{array}{l}\text { Genel } \\
\text { Muhasebe } \\
\text { Harf Notu }\end{array}$} & Cinsiyet &,- 028 & ,013 &,- 013 & $-2,119$ & ,034 \\
\hline & Yaş & ,032 & ,006 & ,035 & 5,353 &, 000 \\
\hline & Kayıt Türü &,- 037 & ,017 &,- 015 & $-2,260$ &, 024 \\
\hline & AGNO & ,415 & ,004 & ,671 & 101,523 &, 000 \\
\hline & Kaçıncı alınış &,- 106 & ,014 &,- 047 & $-7,461$ & ,000 \\
\hline & Sinif & ,019 & ,002 &, 054 & 8,453 &, 000 \\
\hline
\end{tabular}

Genel Muhasebe dersini alan öğrencilerin başarı notlarını öngören değişkenleri saptamak amacıyla başka bir ifadeyle öğrencilerin başarı durumlarına değişkenlerin katkısını belirlemeye yönelik gerçekleştirilen çoklu regresyon analizi sonuçlarına göre, toplam varyansın \%46'sını belirlenen değişkenlerin açıkladığı $\left(R=0,681, R^{2}=0,464, P=0,000\right)$ ve tüm değişkenlerin \%5 önem düzeyinde anlamlı olduğu tespit edilmiştir. Başka bir ifadeyle öğrencilerin Genel Muhasebe dersi notundaki değişimin \%46,4'ü modelde yer alan bağımsız değişkenlerdeki değişimle açıklanmaktadır. Standardize edilmiş regresyon katsayısına $(\beta)$ göre, Genel Muhasebe notunu açıklayan en önemli değişken, öğrencilerin AGNO’larıdır. Genel Muhasebe dersinin başarısı üzerinde yordayıcı değişkenlerin önem derecesi AGNO’yu takiben sınıf, dersin kaçıncı kez alındı̆̆ı, yaş, kayıt türü, cinsiyet değişkenleridir. 


\section{SONUÇ}

Muhasebe dersleri farklı bir mantığa sahip olması ve sayısal içerikli olması nedeniyle hem öğretme açısından eğitimciler için hem de daha önceden dersle ilgili herhangi bir eğitim almamış öğrenciler açısından zor olarak nitelendirilen bir alandır (Fidan, 2012: 4303). Özellikle öğretim elemanı olmadan muhasebe alanındaki derslerin kendi kendine anlaşılması ve öğrenilmesi daha da zorlaşmaktadır. Çalışmanın ana kütlesini oluşturan ATA-AÖF’e kayıtlı Genel Muhasebe dersini alan öğrenciler dersi, öğretim elemanı olmadan kendilerine sunulan yazılı materyaller ve dersi destekleyici $15-25$ 'er dakikadan (her ünite için) oluşan özet videolar üzerinden öğrenmeye çalışmaktadır. ATA-AÖF'ün yazılı materyalleri öğrencilere online olarak sunulmaktadır. Her ders için bir kitap 14 haftalık olarak tasarlanmış olup her hafta öğrenciye bir ünite sunulmaktadır. Her ünite öğrencinin kendi kendine öğrenmesini kolaylaştırmak ve tekdüze olması adına içindekiler, hedefler, giriş, konu anlatımları, özet ve 10 adet değerlendirme sorusundan oluşmaktadır. Ayrıca eğitim materyallerinde konu içindeki önemli noktalar vurgulanmakta (kahverengi italik olarak gösterilmekte) ve her sayfada en önemli görülen noktalar sayfanın yan kısmında 20 kelimeyi aşmayacak şekilde özetlenmektedir. Bu kapsamda çalışmanın amacı, yüz yüze eğitim alan öğrenciler için bile anlaşılması zor alan Genel Muhasebe dersini açıköğretim sistemiyle kısıtlı şartlarla alan öğrencilerin başarılarını etkileyen faktörlerin tespit edilmesidir.

Çalışmada veriler ATA-AÖF bilgi işlem merkezinden sağlanmıştır. Veriler analiz edilirken öncelikle öğrencilerin çeşitli özellikleri bakımından Genel Muhasebe dersi başarılarındaki farklılık incelenmiştir. Bunun için bağımsız örnekler $\mathrm{t}$ testi ve Tek Yönlü (One-way) Anova testi uygulanmıştır. Ayrıca bağımsız değişkenlerin bağımlı değişkeni etkileme durumuna çoklu regresyon analizi ile bakılmıştır. Çalışmanın sonucunda yaş açısından 50 yaşın üstündeki öğrencilerin, kayıtlı olunan program açısından Adalet Önlisans programı öğrencilerinin, kayıt şekli açısından daha önce herhangi bir yükseköğretim kurumundan mezun olup ATA-AÖF'e ikinci üniversite kapsamında kayıtlı olan öğrencilerin, AGNO açısından ise ortalaması 3,00'ın üzerinde olan öğrencilerin Genel Muhasebe dersinde en başarılı öğrenciler olduğu belirlenmiştir. Öğrencilerin Genel Muhasebe dersi başarıları ile söz konusu değişkenler arasında ( $\mathrm{t}$ testi ve Anova testi sonuçlarına göre) da \%5 önem düzeyinde istatistiki olarak anlamlı ilişki olduğu tespit edilmiştir. Genel Muhasebe dersi performansını etkileyen yordayıcı değişkenleri tespit etmek amacıyla yapılan çoklu regresyon analizi sonuçlarına göre ise Genel Muhasebe notunu en iyi açıklayan değişkenin öğrencilerin AGNO'ları olduğu tespit edilmiştir. Muhasebe dersleri ya da muhasebe öğrencilerinin başarıları üzerine yapılan ve literatürde de değinilen birçok çalışmada da aynı sonuca ulaşılmıştır.

Özellikle uzaktan eğitim ve açıköğretim ile gerçekleştirilen eğitimlerde; eğitim ve öğretim ortamlarını zenginleştirmek ve etkin hale getirmek için geliştirilen artırılmış gerçeklik teknolojisi ile başka bir ifadeyle çoklu ortam öğeleri ile desteklenmiş e-kitapların derslerin 
özellikleri dikkate alınarak geliştirilmesi, öğrencilerin başarılarının artmasına katkı sağlayacaktır. Böylece çok farklı özelliklere ve farklı öğrenme stillerine sahip öğrencilere hitap edilmesi kolaylaşacaktır.

\section{KAYNAKLAR}

Adıyaman, Zehra (2002), "Uzaktan Eğitim Yoluyla Yabancı Dil Eğitimi”, The Turkish Online Journal of Educational Technology, 1(1), ss.92-97.

Alanzi, Khalid A. (2015), “Determinants of Students' Performance in Cost AccountingFurther Evidence from Kuwait”, World Journal of Management, 6(1), pp.136-152.

Almunais, Tareq A.-Alfraih, Mishari M.-Alharbi, Faisal M. (2014), "Determinants of Accounting Students Performance”, Business Education \& Accreditation, 6(2), pp.1-9.

Al-Rashed, Wael (2001), "Determinates of Accounting Students' Performance in Kuwait University”, Journal of University of Abdulziz King University Economic And Management, 15(2), pp.3-17.

Al-Twaijry, Abdulrahman Ali (2010), "Student Academic Performance in Undergraduate Managerial-Accounting Courses”, Journal of Education for Business, 85(6), pp.311322.

Balaban, Erdal, “Dünyada ve Türkiye'de Uzaktan Eğitim ve Bir Proje Önerisi”, http://aves.istanbul.edu.tr/ImageOfByte.aspx?Resim=8\&SSNO=2\&USER=686, (14.03.2017).

Booth, Peter-Luckett, Peter-Mladenovic, Rosina (1999), “The Quality of Learning in Accounting Education: The Impact of Approaches to Learning on Academic Performance”, Accounting Education, 8 (4), pp.277-300.

Büyüköztürk, Şener (2011), Sosyal Bilimler için Veri Analizi El Kitabı, 15.Baskı, Pegem Akademi, Ankara.

Demir, Mehmet-Çam, Mustafa (2006), "Muhasebe Bölümü Öğrencilerinin Muhasebe Öğreniminde Başarılarını Olumsuz Etkileyen Faktörlerine İlişkin Bir Araştırma", Muhasebe ve Finansman Dergisi, 32, ss.1-11.

Durmuş, Beril-Yurtkoru, E.Serra-Çinko, Murat (2011), Sosyal Bilimlerde SPSS’le Veri Analizi, 4. Baskı, Beta Basım Yayım Dağıtım, İstanbul.

Eikner, A. Elaine-Montondon, Lucille (2001), “Evidence on Factors Associated with Success in Intermediate Accounting I”, Accounting Educators’ Journal, 8, pp.1-17.

Erol Fidan, Meral (2012), “Üniversitelerde Muhasebe Dersini PowerPoint Sunumu ve Klasik Yöntem ile Alan Öğrenciler Arasındaki Farklılıklar: Bilecik Üniversitesi Örneği’”, Journal of Yaşar University, 25(7), ss.4281-4306. 
Garkaz, Mansour-Banimahdb, Bahman-Esmaeilic, Hadis (2011), “Factors Affecting Accounting Students' Performance: The Case of Students at the Islamic Azad University”, Procedia-Social and Behavioral Sciences, 29, pp.122 - 128.

Gelbal, Selahattin-Kelecioğlu, Hülya (2007), “Öğretmenlerin Ölçme ve Değerlendirme Yöntemleri Hakkındaki Yeterlik Algıları ve Karşılaştıkları Sorunlar”, Hacettepe Üniversitesi Eğitim Fakültesi Dergisi, 33, ss.135-145.

Güngörmüş, Ali Haydar-Uyar, Ali (2010), “Comparison of Accounting and Other Program Students' Performances in Introductory Accounting Course, Suleyman Demirel University The Journal of Faculty of Economics and Administrative Sciences, 15(2), pp.443-453.

Hakan, Ahmet, "Eğitim Sorunlarının Çözümünde Açıöğretim", http://w2.anadolu.edu.tr/aos/kitap/IOLTP/1266/unite04.pdf, (17.02.2017), ss.57-69.

Hatunoğlu, Zeynep (2006), "Muhasebe Eğitiminde Bilgi Teknolojisinin Kullanımının Sunum Kalitesine Olan Etkilerinin Tespitine İlişkin Bir Araştırma”, Muhasebe ve Finansman Dergisi, 30, ss.190-200.

http://www.egitimtercihi.com/ayindosyasi/12194-uzaktan-egitim-dunyada-ve-turkiye-degiderek-yayginlasiyor.html, (18.02.2017).

http://www.osym.gov.tr/Eklenti/1214,sinavsizpdf.pdf?0, (20.04.2017).

https://istatistik.yok.gov.tr/yuksekogretimIstatistikleri/2017/2017_T1.pdf, (19.03.2017).

https://www.anadolu.edu.tr/acikogretim/acikogretim-sistemi/acikogretim-sistemi-1

Jansen, Jade-Villiers, Charl de (2016), "Determinants of Student Performance in An Accounting Degree Programme”, South African Journal of Accounting Research, 30(1), pp.1-28.

Kalbers, Lawrence P.-Weinstein, Gerald P. (1999), "Student Performance in Introductory Accounting: A Multi-Sample, Multi-Model Analysis”, Accounting Educators’ Journal, XI, pp.1-28.

Karasioğlu, Fehmi-Haluk Duman (2011), "Meslek Yüksekokullarında Muhasebe Eğitimi ve Kalitesi Üzerine Bir Not”, Gaziantep Üniversitesi Sosyal Bilimler Dergisi, 10(1), ss.165-180.

Karataş, Serçin (2008), İnternet Temelli Eğitim (Temel Kavramlar ve Kuramsal Temeller), Editör: Halil İbrahim Yalın, Nobel Yayın Dağıtım, Ankara.

Kirk, Florence R.-Spector, Charles A. (2006), “Factors Affecting Student Achievement Cost Accounting”, Academy of Educational Leadership Journal, 10 (1), pp.91-104. 
Kukreja, Gagan-Aali, Mariam Habib Al (2013), “The Determinants of Students’ Performance in Introductory Accounting Courses: Evidence from Kingdom of Bahrain”, Journal of Emerging Issues in Economics, Finance and Banking, 1, pp.183-201.

Kutlu, Hüseyin Ali- Öztürk, Seyhan (2015), "Muhasebe Eğitiminde “Alternatif Ölçme ve Değerlendirme Yöntemleri” Üzerine Görüşler”, Journal of Accounting, Finance and Auditing Studies, 1(4), ss.1-22.

Mutlu, M. Emin-Beyaz Korkut, Melda-Yılmaz, Ülkü (2006), "Ders Kitaplarının Dağıtımı Amacıyla İnternetin Kullanılması: Açıköğretim e-Kitap Uygulaması Örneği”, 6th International Educational Technology Conference Proceedings, 3, ss.1270-1277.

Nyikahadzoi, Loveness-Matamande, Wilson-Taderera, Ever-Mandimika, Elinah (2013), "Determinants of Students' Academic Performance in Four Selected Accounting Courses at University of Zimbabwe”, Research in Higher Education Journal, 21, pp.19.

Onat, Osman Kürşat- Akın, Osman (2016), "Y Kuşağı ve Muhasebe Eğitimi-Durum Tespiti ve Öneriler: Mehmet Akif Ersoy Üniversitesinde Bir Araştırma”, EUL Journal of Social Sciences, VII (II), ss.144-161.

Papageorgiou, K.-Halabi, Abdel K. (2014), "Factors Contributing Toward Student Performance in A Distance Education Accounting Degree”, Meditari Accountancy Research, 22 (2), pp.211-223.

Ramadan, Sayel-Quraan, Anwar (1994), “Determinants of Students' Performance in Introductory Accounting Courses”, Journal of King Saud University, Administrative Sciences, 6(2), pp.65-80.

Sayın, K. Şevket-Yeğinboy, E. Yasemin-Tektüfekçi, Fatma (2005), “Dokuz Eylül Üniversitesi İ.İ.B.F.'nde Öğrenci Açısından ve Alt Yapı Bakımından Muhasebe ve Finansman Eğitiminin Etkinliğinin Ölçülmesi ve Değerlendirilmesi Üzerine Bir Araştırma”, Muhasebe ve Finansman Dergisi, 25, ss.101-108.

Tarakçıŏlu Altınay, Ayşenur (2016), "Muhasebe Eğitiminin Geleceğine Stratejik Bir Bakış”, İnsan ve Toplum Bilimleri Araştırmaları Dergisi, 5(7), ss.2144-2150.

Tugay, Osman-Ömürbek, Vesile (2014), "Meslek Yüksekokullarında Verilen Muhasebe Derslerinin Uygulamada Kullanılma Düzeyi ve Yeterliliği Üzerine Bir Araştırma”, Niğde Üniversitesi İİBF Dergisi, 7 (3), ss.53-74.

Uyar, Ali-Güngörmüş, Ali Haydar (2011), "Factors Associated with Student Performance in Financial Accounting Course”, European Journal of Economic and Political Studies, 2, pp.141-156. 
Waples, Elaine-Darayseh, Musa (2005), “Determinant of Students' Performance in Intermediate Accounting”, Journal of College Teaching\&Learning, 2(12), pp.87-91.

Wooten, Thomas C. (1998), "Factors Influencing Student Learning in Introductory Accounting Classes: A Comparison of Traditional and Nontraditional Students", Issues in Accounting Education, 13(2), pp.357-373.

Yücenurşen, Mehmet-Bezirci, Muhammet-Özpeynirci, Rabia, Peker-A. Aykut (2016), "Muhasebe Eğitimi ve Kalite Boyutları: Türkiye Alan Araştırması", International Journal of Human Sciences, 13(1), ss.296-308. 